\title{
From Education for Profit to Education for Excellence An Inspiration to the Successful Internationalization of Higher Education in Singapore
}

\author{
Jing Lin \\ Sub-Institute of Science Technology and Art, Jingdezhen Ceramic Institute, Jingdezhen, Jiangxi, China, \\ 333000 \\ shenghong666@163.com
}

Keyword: Singapore; Higher education; Inspiration; Profit; Excellence

\begin{abstract}
For the lack of natural resources, during conducting the strategy of developing both economy and society, Singapore's government put education as the fundament of this country, making it owns a special significance. Schools in Singapore educate students in a way which is built on national conditions, creating a distinctive campus culture. It is all-covered, vivid in practice, well-organized, right-hand and effective. Furthermore, Its education being international, professional, and modern, Singapore has become a top performer in education with the great campus culture. Having brought us many inspirations, this success is worth learning.
\end{abstract}

\section{Introduction}

Since its independence in 1965, Singapore, which earns its fame as "citizens here are civilized; economy here is developed; education here is advanced" and "garden city", has not only created a miracle in the history of world economy development, but also been a pioneer who leads the direction of basic education by changing its direction of education from "Education for survival" to "Education for profit", and then "education for excellence". Several years ago, Li Guangyao, the senior minister of Singapore, has once spoken in a meeting: "We've brought Singapore from Third World to First World by the joint effort of our generation of leaders." The trend of developing education is internationalization. The outstanding characteristics of education in Singapore are international, professional, and modern. How can universities in Singapore promote internationalization in only 40 years and become top universities in the world so rapidly? What is the secret of education in Singapore's becoming good from bad, and being famous as "paragon of modern civilization in East Asia"?

\section{Government Plays a Leading Role in the Revolution and Development of Education}

Singaporean government emphases that education is the fundament of social and economic progress, therefore, the revolution and development of education matters a lot. In order to ensure the strategic position of education, powerful measures are taken by the official:

Highlighting the Leading role Played by the Government. tone of education was education for survival. During this period, promoting universal education and establishing a flawless system of education were the most important things to do; 1979-1996, the focus tended to be "effective". Agreeing the education system of "one standard for everyone", the country practiced the model of unified education, which led to $20 \%-30 \%$ dropping out rate and it was not effective. Furthermore, forcing student to learn religion knowledge provoked conflicts between races and religions; 1997-today, ability become a big part of education, and get rid of the unified model, making it a diversification one. By creating a student-focused environment, providing a proactive and balanceable curriculum, pl The system of government is the first level central government centralized autocracy, which means that all the policies of this country are made by government, i.e, the 
Cabinet. Since its independency, the system of education has been a centralizational one to operate in coordination with the pace of economy. Singaporeans are very aware the result of social unrest, and therefore, a steady nation is far more important than democracy. Government almost in charge of all kinds of plans and decisions of education, guiding it to grow rapidly, providing the developing economy with suitable person. Every education revolution is pushed by the powerful government, take the system of distributary of grade 4 in primary school for example, which is established by the government gradually after several times of planning, researching.

The changing of education system in Singapore can be divided into 3 steps: 1959-1978, the main anting teaching group of higher qualities, and persuing an excellent administration, Singapore can develop and become an educational centre one day. Wu Zuodong has expressed his vision for education in the 7 th International Conference of Thinking: "Schools which value thinking; citizens who value learning". He also emphased that, the system of education should be perfect: self-government schools and education for excellent are important, and the government should also expand the education of junior colleges, distribute students by their abilities. It is supposed to be couraged for different students to choose different value of life, take the right path by the demand of society, and have their own choices in different periods of their lives.

Combining Centralization and Decentralization_a an Eastern Democracy. The democracy in the western countries is not applied mechanically in Singapore, but is adsorbed and refined according to the state, which is called "an eastern democracy" by Li Guangyao. This kind of Singaporean democracy is the political insurance of the harmonious society.

While making developing plans for the whole country, the government makes developing plans for education according to the demand of society. Planning for education is seen as a significant way to strengthen macro-control of government. In different phases of economy's development, the counterpart of education's refining should be conducted, to maintain the synchronism of economy and education. Every time its economy begins to transfer, its fundamental education system would provide support to its transference. In Singapore, four revolutions of education were around it.

In order to avoid restraining the development of education and the enthusiasm of schools because of the centralization, Singaporean government promotes the policy of "make schools private", "self-government", etc., letting it become a decentralization one.

This kind of system is suitable for the state quo of this little island country.

Democracy and Science Promote the Benign Development of National Education. The duty of Ministry of Education in Singapore is "to create the future of Singapore", and the vision of it is "schools which value thinking; citizens who value learning", the guiding principle of it is "facing to the development, people first, excellence, effectiveness, fairness, balance, diversification, and innovation". The plan for it is low to up, and the support for it is the other way round. Its education is made by the state quo of the country. Democracy and science promote the benign development of national education, approaching to the advanced education in the world.

Teachers take part in making policies which involved with their work, and they are given enough authority to do their jobs. They share common senses and senses of belonging. Whoever makes contributions, would be appreciated and respected by colleagues. Teachers decide the curriculum together, talk and improve approaches of teaching.

Governments of Singapore starts positively from the ethnical education of schools, especially colleges. A series of measures have been taken to teach ethnical education to them potentially, and it will be reflected to their ideology and behavior. Nation first and patriotism is the main tone of the ethnical education of Singapore, and it have distinctive characteristics: patriotism and collectivism are brought up in universities, and students are taught to become a contributor to society, and the society needs and will cherish their contribution. The new frame is "Head, Heart, and Hands". Every student should be aware of their relationships with environment, and consider their contributions to others, which is the pith of its culture. 
Inspiration of Surpassing Based on Strong Sense of Hardship. Mencius famous book, "Life springs from sorrow and calamity, death comes from ease and pleasure" shows a kind of fierce sence of crisis and hardship, which is the eternal motivation for the development of Singapore. Singaporeans know clearly that, their homeland is not only narrow, small, and lack of natural resources, even fresh water, sand used to conduct the land reclamation are imported from other countries. Lacking of resources corners it. If Malaysia stops providing Singapore the fresh water, Singapore will become an adust city over one night. For 40 years, the government keeps reminding citizens of maintaining the sense of hardship.

There is a story in the historical reading matters in Singapore's high school, which tells the story of Emperor Taizong of Tang. He saw how the Sui Dynasty fell because of extravagance, so he said: "Providing against danger while living in peace, never extravagance" to educate his people. Public servant system in Singapore is especially strict.

A Society under the Law in Eastern Style. Singapore is a country under the law, and it is also called "City of Fine", for the fines to unmerited behaviors are extremly strict. Smoking in public areas, spitting, not flushing the toilet, and so on, which are seem to be common behaviors in China, will get S\$ 1000's fine in Singapore. There're laws to obey no matter in life or work from political system, management of finance to rules of parking, public sanitation, and people's behavior and life.

There is a story in history education in primary and secondary schools: Once Emperor Zhu Yuanzhang asked his courtiers in the morning meeting: who is happy in the world? The courtiers hold different opinions, some said those successful people were happy; some said those who won first place in examination is happy and some said rich people are happy. Zhu Yuanzhang felt unhappy about those answers. In the end, a courtier named Wang Gang said: those people who are afraid of laws are happy. Zhu Yuanzhang burst into smile and praised him for its particular opinion. If you have been rich for a long time, you would corrupt, if you corrupt, you would break the laws. In Singapore, everybody knows that simple principle so that they make such a lush, green and honest modern city in the world.

Strengthen Nationality's Value by Promoting Traditional Festivals. Population in Singapore is mostly Chinese, so the government's opinion towards this is strengthening the attraction of traditional festivals is better than resisting the influence of diversification. Traditional festivals are highlighted in the promotion of Chinese traditional culture. There are colorful activities to explain the origin of the festival, and there is ceremony, traditional food of that day for people to enjoy. Traditional festival is the symbol of a nation's history and experiences, reflecting the changes of its culture, arousing the impression of history and culture for the individuals and groups, and the value, spirituality, ethnicity, too. Traditional festivals are becoming the source of happiness to people, and by exploding, digging, creating and advertising it, people will know traditional festival better, and enjoy, join it. The traditional culture will be rooted in the land and will not be invaded by the outside cultures.

\section{Resisting Negative Cultural Infiltration by Classical Confucian}

Under the circumstances of becoming western-like, government in Singapore takes education of traditional Chinese culture as a vital measure to erase the influence brought by the negative western culture, and refresh the spirits of nation. Moral education is being connected with the existence of nation and country. Because of it, in the phase of primary education, it is the most important things for them to strengthen moral education, develop the awareness of nation, which enable college students to resist rust culture of west by themselves, especially the wave of out-and-out egoism.

For example, De Ming High School has a statue of Confucius, Hai Xing High School has quotations from The Analects of Confucius, and old saying like "loyalty and filial piety, honesty and honor, kindness and peace". Head master holds the opinion that the model of people of sanity will do good to the development of patriotism and their values and habits. He also likes the Mencius and Confucius and their theories like "kindness" and he advices the students to read the classical works as an instruction to their behavior and 
thinking, enabling them to learn from tradition and build up their values without the bad effect of western cultures.

"Peace is valuable", "A gentleman gets along with others, but does not necessarily agree with them". Those philosophies are also reflected there, which becomes the principle of building up new Singapore culture. The harmony in different races and the promotions of the root of Chinese culture in Singapore mental education play important roles.

In art subjects like history and geography, and in the daily life, governments in Singapore are promoting the Confucian. According to the theory of "Learning without thought is labor lost, thought without learning is perilous", Singapore raises its vision "schools which value thinking; citizens who value learning". It pushes political and economical revolutions, which keep pace with the procedure of industrialization, and adapt to the changes of industry, insure the same pace of economy and education. Every time its economy begins to transfer, its fundamental education system would provide support to its transference. Seeing from the background of globalization and knowledge economy, the direction of education's development is a success.

\section{Conclusion}

Singapore accumulate rich experience in the revolution and development of education, based on drawing successful experience of other developed countries, Singapore carry out pluralistic revolution and experiments, the modern education in Singapore has features of compression, which is compressed modernization. Western countries spend three centuries to achieve educational modernization, while Singapore only spend several decades to achieve it. Especially he takes in the examination-oriented education which is emphasized in China and the open-minded teaching in western counties, inherit Chinese long history and the root in Confucianism culture, build up humanistic culture, and shape the future educational philosophy, which gives us lots of inspirations.

\section{References}

[1] Yang Yudong: The Successful Experience of Basic Education Revolutions in Singapore, from Tianjing Education, 2010, 12th.

[2] Ronald Takaki, adapted by Rebecca Stefoff: Enhnic island, the emergence of urban Chinese Singapore New: Chetsea House, 1994.

[3] Chow, Jesse Chain: A survey of Chinese students in the Singapore 1979-1987 Ann Arbor. Mich, VM.L, 1995. 